\title{
Pharmacognostic and hypoglycemic studies of Achyranthus aspera L.
}

\author{
Ishtiaq Ahmad ${ }^{1}$, Muhammad Ibrar ${ }^{1}$, Barkatullah $^{1}$, Naveed Muhammad $^{2 \star}$, Zahir Muhammad $^{1}$ \\ and Niaz Ali ${ }^{1}$ \\ ${ }^{1}$ Department of Botany, University of Peshawar, Peshawar, KPK, Pakistan. \\ ${ }^{2}$ Department of Pharmacy, Hazara University, Havelain Campus, Abbottabad, KPK, Pakistan.
}

Accepted 27 May, 2013

\begin{abstract}
In the present study, the ethanolic extract of Achyranthus aspera L. Leaves (EEA) were investigated for their pharmacognostic characteristics and hypoglycemic effects. The pharmacognosy of the plant was carried out using microscopic and macroscopic tools. Macroscopic studies revealed that the leaves were cauline, ramel, opposite, exstipulate, simple, sub-sessile, ovate, entire, acute, unicostate, reticulate, rough, coriaceous and hairy. The stem was erect, herbaceous, quadrangular, branched, solid, green and pubescent, while various internal parts were observed using powder drug for microscopic study. The hypoglycemic effect of the plant was studied in healthy normoglycemic rabbits. The EEA was tested in three doses $(100,150$ and $200 \mathrm{mg} / \mathrm{kg})$, and a dose dependent hypoglycemic effect was observed. The most significant hypoglycemic effect was observed against higher dose (200 $\mathrm{mg} / \mathrm{kg}$ ) which remained for $5 \mathrm{~h}$ while the hypoglycemic effect remained significant for $3 \mathrm{~h}$ against the lower dose. It was concluded that EEA has hypoglycemic properties and it is recommended for the treatment of diabetes mellitus II.
\end{abstract}

Key words: Pharmacognostic, hypoglycemic, Achyranthus aspera L.

\section{INTRODUCTION}

Achyranthus aspera L. is a common perennial herb, growing as a wild plant, in natural and cultivated habitats. $A$. aspera $L$. has a branched tap root system. The stem is herbaceous, quadrangular, branched, solid, green and pubescent. Leaves are simple and exstipulate. A spike type of recemose inflorescence occurs in this specimen. Almost all parts (seed, root, stem and leaf) of $A$. aspera L. possess medicinal value (Lans, 2007) but leaves have greater importance in the traditional (unani) system of health and herbal medicine formulation. Alcoholic decoctions of $A$. aspera $\mathrm{L}$. are mostly used as anti-inflammatory (Girach Aminuddin and Khan, 1992) and infertility inducing agents (Chakraborty et al., 2002; Shibeshi et al., 2006). Furthermore, the plant possesses lavicidal (Bagavan et al., 2008), antioxidant (Edwin et al., 2008), anticancer (Chakraborty et al., 2002), anti- diarrheal and antidysentric (Boily and Van Puyvelde

, 1986; Girach Aminuddin and Khan, 1992), antimicrobial (Boily and Van Puyvelde, 1986) properties. The hypoglycemic effect of methanolic and aqueous extract of the whole plant of $A$. aspera has been reported (Akhtar and lqbal, 1991). The pharmacognostic profile and hypoglycemic effect of the leaves of this plant was studied in order to validate traditional uses.

\section{MATERIALS AND METHODS}

Plant

The study was conducted in the Department of Botany, University 
of Peshawar. Plants of $A$. aspera was collected from different localities in the district of Charsadda, KPK, Pakistan. Plants were identified by Dr. Muhammad Ibrar, Department of Botany, and specimen was deposited there in the herbarium under voucher number 7455/Bot. The whole plant was powdered for microscopic study.

\section{Preparation of extract}

The ethanolic extract of the leaves was prepared using our previous reported method (Barkatullah et al., 2011; Muhammad and Saeed, 2011; Muhammad et al., 2012b, c). Powder of leaves was macerated in ethanol for 10 to 15 days. The extract was filtered and then evaporated. The dry extract was stored in refrigerator for use.

\section{Animals}

Domesticated rabbits weighing $1 \mathrm{~kg}$ obtained from the district Charsadda District, Pakistan were used. The animals were kept at standard laboratory conditions. The animals were shifted from animal house to the laboratory one hour prior to start the experiment.

\section{Pharmacognostic study}

The pharmacognostic profile of the plant was reported using our previous reported method (Muhammad et al., 2012; Ismail et al., 2011). Vein islet number, vein termination number, palisade ratio, stomatal number and stomatal indices were calculated from $1 \mathrm{~mm}^{2}$ pieces of leaf of $A$. aspera boiled in concentrated chloral hydrate solution under high power compound microscope.

\section{Macroscopical features}

The following macroscopic characters of plant were noted: size, shape, margins, apex, surface, color, odour, taste, nature, texture of leaves, stem and root were also studied (Wallis, 1985; Evans and Trease, 2002).

\section{Powder drug Study}

Powdered drug was studied using chloral hydrate and iodine solution under compound microscope (Compoud microscope). Organoleptic evaluation (color, odour, taste, fracture and touch) of the powdered drug was done using five senses (Pharmacopoeia, 1986).

\section{Phytochemical Study}

\section{Qualitative chemical identification tests}

Various phytochemical tests were performed for detection of various constituents preliminary, using well established procedures (Trease and Evans, 1989; Muhammad and Saeed, 2011).

\section{Hypoglycemic effects}

The healthy rabbits were divided into five groups of six. Group I was treated with normal saline $(10 \mathrm{ml} / \mathrm{kg})$ and acted as a control, Group II was treated with the standard hypoglycemic drug, glibenclimide,
Group III, IV and V were treated with the ethanolic extract of Achyranthus aspera (EEA) at doses of 100,150 and $200 \mathrm{mg} / \mathrm{kg}$, respectively. Blood glucose level was noted at the start of the experiment and then after 1, 2, 3, 4 and $5 \mathrm{~h}$, respectively. Glibenclimide was used as a standard hypoglycemic drug. Swab soaked in methylated spirit was used as a disinfectant during collection of blood. Blood was obtained by puncturing the veins in the pinna of each animal by using a sharp lancet. A swab soaked in methylated spirit was used to disinfect the lancet after each use.

\section{RESULTS}

\section{Macroscopical features}

Leaves of $A$. aspera $L$. are cauline, ramel, opposite, exstipulate, simple, sub-sessile, ovate, entire, acute, unicostate, reticulate, rough, coriaceous and hairy. The stem is erect, herbaceous, quadrangular, branched, solid, green and pubescent. A tap and branched root system is present.

\section{Microscopical features}

Vein islet No., vein termination No., palisade ratio, stomatal No., and stomatal index are given as in Table 1.

\section{Powder drug study}

Trichomes of various types that is, multicellular, shagay, uniciniate, uniseriate etc (a-d), glandular hairs (e-f), tracheids (I), parenchyma cells (j), mesophyll cells (i), fragments of small veins (h), starch granules (g), fragments of epidermis and stomata $(\mathrm{k})$ were found in the powder drug. Organoleptic evaluation of the powder drug is as seen in Figure 1.

\section{Phytochemical screening tests}

Alkaloid, saponin, lignin, ca-oxalate, starch, protein, mucilage, tannin were identified in the plant extract. (Table 2).

\section{Hypoglycemic effect}

The hypoglycemic effects of ethanolic extracts of $A$. aspera L. was compared with standard (glibenclamide). Both standard and ethanolic plant extracts reduced the blood glucose level of rabbits significantly $(\mathrm{P}<0.05)$. The result showed that ethanolic plant extracts of $A$. aspera $\mathrm{L}$. possess strong hypoglycemic effects. Higher doses of plant extract is more effective in decreasing blood glucose level when compared to low doses. The efficacy of low doses last for 2 to $3 \mathrm{~h}$ while high doses last for more than $3 \mathrm{~h}$. (Table 3). 


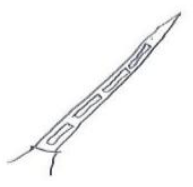

a

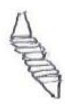

e
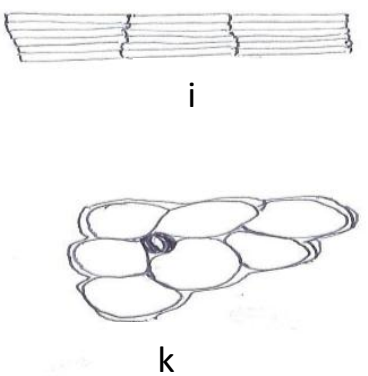

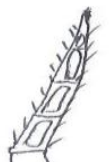

b

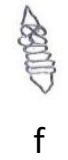

f

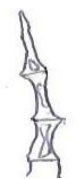

$\mathrm{C}$

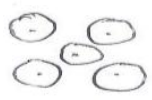

g
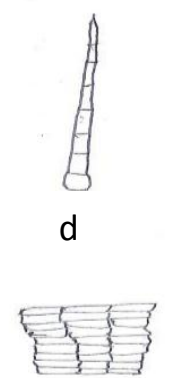

$\mathrm{h}$

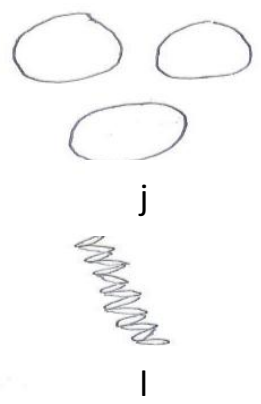

Figure 1. Powder drug study of the $A$. aspera. Multicellular (a), shagy (b), uniciniate (c), uniseriate (d), glandular hairs (e-f), starch granules $(\mathrm{g})$, fragments of small veins (h), mesophyll cells (i), parenchyma cells (j), fragments of epidermis and stomata (k) and tracheids (I).

Table 1. Organoleptic evaluation of $A$. aspera leaves.

\begin{tabular}{cll}
\hline S/No & Parameter & Observation \\
\hline 1 & Color & Dark green \\
2 & Odour & Pungent \\
3 & Taste & Slightly disagreeable \\
4 & Fracture & Fibrous \\
5 & Touch & Soapy \\
\hline
\end{tabular}

\section{DISCUSSION}

The pharmacognostic profile is essential for crude drugs as it helps in the identification of specific drugs within the same genus. There are several plants within the same genus with similar structure and with different microscopic characteristics, however the medicinal value of these morphological similar plants vary from each other. Pharmacognostic studies help in the identification of specific plants possessing organoleptic and microscopic characteristics (Ismail et al., 2011).

Glibenclamide is a sulfonylurea derivative and commonly used in the management of diabetes mellitus type II; it causes hypoglycemia by stimulating beta cells of pancreas and increasing release of insulin and inhibiting glucagon secretion. As these effects require a functional pancreas, it can lower blood sugar levels in non-diabetic subjects (Soon and Tan, 2002) and a similarity was obtained in our tested ethanolic extract. It is very interesting to note that the ethanolic extract of the leaves of our selected plant is used in the tradition system of medicines in the management of various ailments. Our results show that the extract can decrease the serum glucose level in normoglycemic individuals. However, an adverse effect is that the plant can decrease the normal glucose level, just like glibenclamide, therefore, it is recommended that in the use of this plant as an anti-inflammatory or even for diabetic management, the glucose level should be monitored periodically. It is also worth mentioning that the plant should not be used in high doses for the treatment of ailments other than diabetes because it lowers the normal serum glucose level in normal patients.

In diabetes, oxidative stress has been found to be mainly due to an increased production of oxygen free radicals and a sharp reduction of anti-oxidant defenses (Oberley, 1988; Brownlee, 2001; Muhammad et al., 2012a). Hence, compounds with both hypoglycemic and anti-oxidative properties would be useful anti-diabetic agents (Brownlee, 2001). It has been reported that the methanolic extract of $A$. aspera is a good antidiabetic and antioxidant (Akhtar and Iqbal, 1991; Edwin et al., 2008) agent. The phytochemical study revealed the presence of 
Table 2. Phytochemical screening of the EEA.

\begin{tabular}{llc}
\hline Phytochemicals & Result & Remarks \\
\hline Alkaloid & Reddish brown & ++ \\
Saponin & Frothing & ++ \\
Lignin & Pink coloration & ++ \\
Ca-oxalate & Dissolve in HCl without effervescence & ++ \\
Starch & Deep blue coloration & ++ \\
Protein & Yellow ppt. & ++ \\
Mucilage & Gummy suspension & ++ \\
Tannin & Greenish coloration & ++ \\
\hline
\end{tabular}

Table 3. Effect EEA on blood glucose level of normoglycemic rabbits.

\begin{tabular}{|c|c|c|c|c|c|c|}
\hline Treatments $(\mathrm{mg} / \mathrm{kg})$ & $\mathbf{O h}$ & $1 \mathrm{~h}$ & $2 \mathrm{~h}$ & $3 \mathrm{~h}$ & $4 \mathrm{~h}$ & $5 \mathrm{~h}$ \\
\hline Control & $153 \pm 2$ & $151 \pm 1.5$ & $152 \pm 2$ & $149 \pm 2$ & $147.7 \pm 2.5$ & $142.3 \pm 1.15$ \\
\hline Glb (0.2) & $153.7 \pm 1.5$ & $111.3 \pm 2.1^{\star \star}$ & $113.6 \pm 1.5^{\star \star}$ & $117.3 \pm 2.5^{\star \star}$ & $120.3 \pm 1.5^{\star \star}$ & $122.7 \pm 1.5^{\star \star}$ \\
\hline EEA (100) & $149.7 \pm 1.5$ & $114.3 \pm 2.1^{* *}$ & $118 \pm 2^{\star \star}$ & $123.6 \pm 2.5^{\star *}$ & $133.7 \pm 3$ & $139 \pm 2.6$ \\
\hline EEA (150) & $144 \pm 2$ & $109.7 \pm 2.5^{\star *}$ & $127.7 \pm 2.1^{* *}$ & $131.3 \pm 2.1^{* *}$ & $133 \pm 2$ & $135.3 \pm 2.1$ \\
\hline EEA (200) & $150.7 \pm 2.5$ & $90.6 \pm 2.1^{\star *}$ & 101. $0 \pm 1.5^{\star *}$ & $111.3 \pm 2.5^{\star *}$ & $116.7 \pm 1.5^{\star *}$ & $124.7 \pm 1.5^{\star *}$ \\
\hline
\end{tabular}

$\mathrm{Glb}=$ Glibenclamide, Data presented as mean \pm SEM $(n=6) .{ }^{*} \mathrm{P}<0.05,{ }^{*} \mathrm{P}<0.01$.

starch which produce hyperglycemia but the presence of alkaloids, saponin and tannin in our results as hypoglycemic. Besides $A$. aspera $\mathrm{L}$, many other plants like Averrhoa bilimbi (Pushparaj et al., 2000) and Indigofera pulchra (Tanko et al., 2008) have hypoglycemic effects on blood glucose level of normoglcemic rats. While plants like Nauclea latifolia (Gidado et al., 2005), Rhinacanthus nasutus (Rao and Naidu, 2010) and Veranonia amygdalina (Michael et al., 2010) show hypoglycemic effects in alloxin and streptozocin induced diabetic rats but have no pronounced effects on blood glucose in normoglycemic rats.

\section{Conclusion}

The ethanolic extract of the leaves of $A$. aspera validates its use as a hypoglycemic drug. It can be used safely for the treatment of diabetes type two, however in certain cases, use of the drug by non-diabetic patient in high doses will lower the normal glucose level. It is therefore recommended that the plant should not be used in large doses for the treatment of non-diabetic conditions.

\section{REFERENCES}

Akhtar, Iqbal J (1991). Evaluation of the hypoglycaemic effect of Achyranthes aspera in normal and alloxan-diabetic rabbits. J. Ethnopharmacol. 31:49-57.

Bagavan A, Rahuman A, Kamaraj C, Geetha K (2008). Larvicidal activity of saponin from Achyranthes aspera against Aedes aegypti and Culex quinquefasciatus (Diptera: Culicidae). Parasitol. Res. 103:223-229.
Barkatullah IM, Muhammad N (2011). Evaluation of Zanthoxylum armatum DC for in-vitro and in-vivo pharmacological screening. Afr. J. Pharm. Pharmacol. 5:1718-1723.

Boily Y, Van PL (1986). Screening of medicinal plants of Rwanda (Central Africa) for antimicrobial activity. J. Ethnopharmacol. 16:1-13.

Brownlee M (2001). Biochemistry and molecular cell biology of diabetic complications. Nature 414: 813-820.

Chakraborty A, Brantner A, Mukainaka T, Nobukuni Y, Kuchide M, Konoshima T, Tokuda H, Nishino H (2002). Cancer chemopreventive activity of Achyranthes aspera leaves on Epstein-Barr virus activation and two-stage mouse skin carcinogenesis. Cancer Lett. 177:1-5.

Edwin S, Jarald EE, Deb L, Jain A, Kinger H, Dutt K, Raj AA (2008). Wound Healing and Antioxidant Activity of Achyranthes aspera. Pharmaceut. Biol. 46:824-828.

Evans WC, Trease (2002). Pharmacognosy. WB Saunders Ltd. London. pp. 32-33, 95-99, 512, 547.

Gidado A, Ameh D, Atawodi S (2005). Effect of Nauclea latifolia leaves aqueous extracts on blood glucose levels of normal and alloxaninduced diabetic rats. Afr. J. Biotechnol. 4:91-93.

Girach AR, Khan S (1992). Ethnomedicinal Uses of Achyranthes sapera L. in Orissa (India). Pharmaceut. Biol. 30:113-115.

Ismail M, Rahman S, Muhammad N, Mohani N, Khan MA, Barkatullah, Hussain J ( 2011). Pharmacognostic and phytochemical investigation of the stem bark of Pistacia integerrima Stew ex Brandis. J. Med. Plants Res. 5:3891-3895.

Lans C (2007). Comparison of plants used for skin and stomach problems in Trinidad and Tobago with Asian ethnomedicine. J.Ethnobiol. Ethnomed. 3:13.

Michael UA, David BU, Theophine CO, Philip FU, Ogochukwu AM, Benson VA (2010). Antidiabetic Effect of combined aqueous Leaf extract of Vernonia amygdalina and Metformin in rats. J. Basic Clin. Pharm. 1:197-202.

Muhammad N, Saeed M, barkatullah, Ibrar M, Khan H (2012). Pharmacognostic studies of Viola betonicifolia. Afr. J. Pharm. Pharmacol. 6:43-47.

Muhammad N, Saeed M (2011). Biological screening of Viola betonicifolia Smith whole plant. Afr. J. Pharm. Pharmacol. 5:23232329.

Muhammad N, Saeed M, Adhikari A, Khan KM, Khan H (2012a) Isolation of a new bioactive cinnamic acid derivative from the whole 
plant of Viola betonicifolia. J. Enzyme Inhibition Med. Chem. DOI:10.3109/14756366.2012.702344.

Muhammad N, Saeed M, Khan H (2012b). Antipyretic, analgesic and anti-inflammatory activity of Viola betonicifolia whole plant. BMC Complement. Alternat. Med.12, doi:10.1186/1472-6882-1112-1159.

Muhammad N, Saeed M, Khan H, Haq I (2012c). Evaluation of nhexane extract of Viola betonicifolia for its neuropharmacological properties. J. Nat. Med. DOI:10.1007/s11418-11012-10636-11410.

Oberley LW (1988). Free radicals and diabetes. Free Radical Biol. Med. 5:113-124.

Pharmacopoeia A (1986). African Pharmacopoeia. General methods for Analysis. OAU / STRC Sci. Pub. Lagos 2(2):1-5, 137-149, 223-237.

Pushparaj P, Tan C, Tan B (2000). Effects of Averrhoa bilimbi leaf extract on blood glucose and lipids in streptozotocin-diabetic rats. J. Ethnopharmacol. 72:69-76.

Rao PV, Naidu MD (2010). Anti Diabetic Effect of Rhinacanthus nasutus Leaf Extract in streptozotocin induced diabetic rats. Libyan Agric. Res. Center J. Int. 1:310-312

Shibeshi W, Makonnen E, Zerihun L, Debella A (2006). Effect of achyranthes aspera L. on fetal abortion, uterine and pituitary weights, serum lipids and hormones. Afr. health sci. 6:108-112.
Soon Y, Tan B (2002). Evaluation of the hypoglycemic and anti-oxidant activities of Morinda officinalis in streptozotocin-induced diabetic rats. Singapore Med. J. 43:77-85.

Tanko Y, Abdelaziz M, Adelaiye A, Fatihu M, Musa K (2008). Effects of Hydromethanolic leaves extract of Indigofera pulchra on blood glucose levels of normoglycemic and alloxan-induced diabetic Wistar rats. Int. J. Appl. Res. Nat. Prod.1:13-18. 